\title{
Pakistan's Language Policy and its Enlightenment to China
}

\author{
Shulin Guo \\ Faculty of International Education of Chinese Language \\ Beijing Language and Culture University \\ Beijing, China \\ E-mail: leonshulin@hotmail.com
}

\begin{abstract}
China and Pakistan are friendly neighbors and there are many similarities between them. Pakistan's language status has its own characteristics. Pakistan's language policy is constantly changing. The main manifestation is the competition for official language status between Urdu and English. This has created a number of problems, such as fierce fighting in the two social strata, division of the country, colloquialization of main ethnic languages and national separatism caused by marginalization of local dialects. These facts have provided useful reference and enlightenment for the formulation of Chinese language policy.
\end{abstract}

Keywords-language status; language policy; official language; enlightenment

\section{INTRODUCTION}

Pakistan is a friendly neighbor of China. Since the 1950s, Pakistan's relations with China have been continuously deepening, forming an "all-weather" and "all-round" strategic partnership with China. China and Pakistan support each other politically, fight side by side strategically, cooperate closely economically, and have increasingly close cultural exchanges. In the three years from 2014 to 2016, China trained 1,000 Chinese teachers for Pakistan and supported Pakistani promotion of Chinese language teaching [1]; the Pakistan government also established Pakistan research centers at four domestic universities, including Tsinghua University. To support Chinese young scholars and students went to Pakistan to study language and culture, Pakistan government also set up a Chinese research center and project in Pakistan [2]. Pakistan sent a large number of international students to study Chinese language and for further education in China. Almost all the students who come to China got scholarships, and the scholarships of the Pakistani government and the Chinese government accounted for the majority, and increased year by year. The number of Pakistani students studying at Beijing Language and Culture University, the university where the author is located, has increased significantly. Only the College of Advanced Chinese Training has increased the number of Pakistani students from less than 10 in 2015 to nearly 150 in 2017. The large increase in the number of students has prompted the teachers to gain a certain degree of understanding of their language background, their country's language education and language policy in teaching Chinese as a foreign language, in order to achieve better teaching results.

The study of Pakistani language policy can also provide reference for the formulation of Chinese language policy. On the one hand, Pakistan and China are all multi-ethnic countries and have many languages. They both have major ethnic groups and major common language. Therefore, they have a lot of similarities. On the other hand, unlike China, the official language of Pakistan is not a native language. It is English. The status and role of Urdu as a national language is relatively low, and it is not as important as Mandarin Chinese is in China. The occurrence of this situation is complicated with many reasons such as history, religion, etc., and whether its language policy is one of the reasons are also worth studying.

\section{THE LANGUAGE STATUS NOW IN PAKISTAN}

\section{A. Language Status in Pakistan}

Pakistan has a lot of languages. There is no accurate figure. Some scholars believe that there are more than 60 kinds of languages in Pakistan [3]. It is certain that there are six major languages, including four major dialects - Punjabi, Sindhi, Pashto, and Balochi; but also, the current official language - English. The official documents and legal documents are written in English; there is also Urdu spoken as "Mandarin." What is worth noting here is that although Urdu is regarded as "the national language" and is actually also commonly used in Pakistan, the use of Urdu is limited. The status of Urdu is not yet very high, and it still cannot play a true and complete role in Mandarin. [4]

\section{B. Factors Affecting Pakistan's Language Status}

\section{1) National factors}

Pakistan has multiple languages and is the result of a combination of factors. The main reason is that Pakistan is a multi-ethnic country. From ancient times to the present day, Dravidian peoples, Aryans, Greeks, Seljuks, Jats, Turks, Persians, Gujars, Afghans, Arabs and many others have been brought together on this land[5]. These ethnic groups merged into each other and produced many new races, such as Punjab, Sindh, Pashtun, and Baloch groups. These four major ethnic groups in Pakistan have all formed their own 
languages. The numbers of these four peoples are different. See Fig.1.

Punjabi is an Indo-Aryan language and a big member of Hindi family. Punjabi has the largest number and influence in comparison with the other three because of the largest number of Punjabis in Pakistan. Sindhi also belongs to Hindi and is the second largest dialect in Pakistan. Both Pashto and Baluchi belong to Iranian language family, with less use and influence than the first two dialects [5].

\section{2) Religious factors}

The establishment of Urdu's status in Pakistan's "Mandarin" is related to religion. Pakistan is a Muslim country, and Islam is the foundation of its country. In the division of India and Pakistan, the Muslim group that ultimately led Pakistan to independence used Urdu as their own language instead of Hindi. Since the date of the founding of the country, the status of Urdu's national language has become unbreakable.

In fact, Urdu is based on Hindi and is very close to Hindi. It contains a lot of Persian, Arabic and even Punjabi vocabulary. It is written in Arabic letters. It is essentially a mixed language. The native speakers of Urdu account for only $3.3 \%$ of the total population of Pakistan [3]. Therefore, for a long period of time, because of its own characteristics and limitations, Urdu still could not become the most powerful official language of Pakistan.

\section{3) Historical factors (Colonial influence)}

The official language of Pakistan was identified as English, mainly because of historical factors and colonial influence. As a former British colony, English was the official language even before the division of India and Pakistan. Recently, the documents and legal texts of Pakistani government at all levels are still mainly written in English. Most urban schools use English as their teaching language. Urdu only learns as a discipline. Although in recent years, more and more nationalists request to improve Urdu status, the ruling cliques and intellectuals with higher status have maintained English as the first official language because of their need for close communication with the Western world.

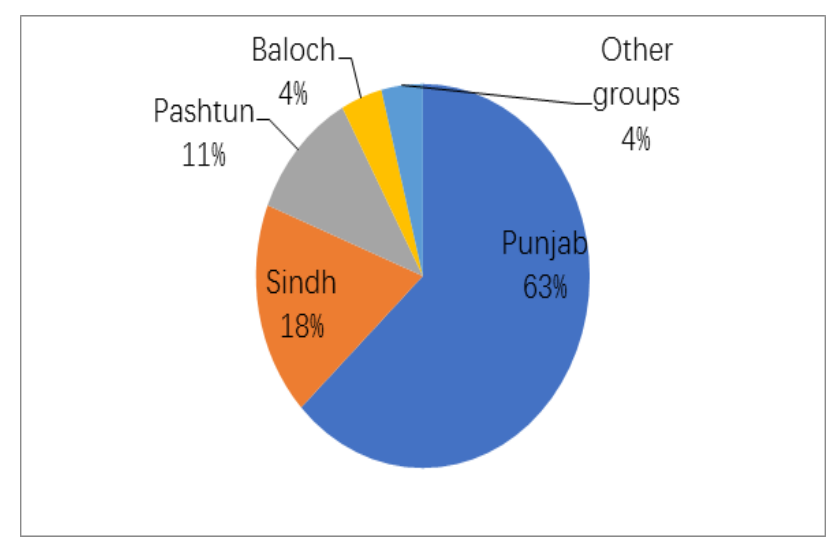

Figure 1. Ethnic composition of Pakistan

\section{Education in Pakistan}

The language situation in Pakistan is also the result of its education. In Pakistan, as of 2012, the literacy rate for the entire population is only $55 \%$. The government's investment in education accounts for less than 3\% of the gross national product. The number of public schools is insufficient. There is a shortage of teachers. During the basic education stage, with the purpose of using foreign investment to improve education in Pakistan, a large number of "public" schools established by government and operated by personal companies. However, the level of education is still lower than the other Asian countries surrounding [6]. In this case, the quality of private schools is obviously higher, and private schools mostly emphasize English learning. Therefore, the status of English cannot be shaken. Urdu has increased with the increase of public schools, but it is still very limited; The major ethnic languages have a serious phenomenon of colloquialism, and their status has decreased instead of rising.

\section{The LANGUAGE POLICY OF PAKISTAN}

\section{A. The Language Policy for the first Decade in Pakistan}

On August 14th, 1947, Pakistan was officially established. At the beginning of the founding of the country, nationalism was rising. The political leaders represented by Jannah actively advocated that Urdu should be used instead of English to become the only official language. Since then, universities have begun to teach in Urdu and translated a large number of Western documents in Urdu. But this only lasted until the mid-1950s. [7]

\section{B. Changes in Language Policy}

As a result of the ongoing political reforms, changes in government rights, and even the division of the country, Pakistan's language policy has been undergoing changes. With the change of the rulers, different language policies have been made.

During the reign of President Ayub Khan from 1958 to 1969, the development of English was essentially encouraged. In the military academy he founded, languages of communication and teaching are both English, prohibiting the use of native languages. The level of the English language has also become an important criterion for promotion in the government. For this, many Urdu groups have been making active efforts to change this tendency of the government.

From the end of the 1960s to the early 1970s, President Yahya Khan went to the other road during his reign. He demanded that before 1975, the teaching languages of all schools at all levels should be changed to Bengali and Urdu. $\mathrm{He}$ also encountered many practical problems and was questioned by all.

In the 1970s, during the administration of Ali Bhutto, "Urdu is the national language" was written in Article 251 of the Constitution. In fact, the people generally believed 
that this was only the appeasement of the middle-class and low-class people who supported Urdu. And English was used as an official language for at least 15 years without doubt.

From the late 1970 s to the 1980 s, Muhammad Zia-ulHaq, who had deep feelings for Urdu, came to power. He once again put forward: Since 1979, all schools must use Urdu to teach. However, with his death in 1988, Urdu's status has not improved much.

Since 1988, during Benazir Bhutto's administration, to enhance the status of English, English was once again supported as a teaching language in all the schools. [7]

\section{Current Language Policy}

Government officials and elites in all fields of society support English. However, the middle-class and lower-class peoples support Urdu. Therefore, the policies that Pakistan government has pursued have been increasing Urdu's status on the surface only. And there is no obstacle to the existence and development of English as an official language.

In recent years, the status of Urdu has always been on the rise. The Pakistani government and the Supreme Court have also asked Urdu to replace English as the official language and have asked all the provinces to complete the "official language change" task as soon as possible.

Nowadays, in rural and most urban primary and secondary schools, Urdu has become the language of instruction; and in private schools and elementary schools in some large cities, English still has an unshakable position. The competition between Urdu and English still has a long way to go.

\section{PROBLEMS DUE TO LANGUAGE POLICY}

\section{A. Fierce Fighting in the two Social Strata}

In Pakistan, the struggle between the two official languages is manifested in the struggle between the upper strata of the society and the middle-class and lower-class strata. To some extent, it forms a linguistic apartheid. Those who support the use of English as the official language are mainly privileged or want to enter the privileged class. They strongly hope that Urdu's replacement of English status is mainly for the common people. Language seems to have become the biggest obstacle to the upward movement of the social class. The contradiction created by the polarization that had previously emerged in the society has also intensified.

\section{B. The Division of the Country}

The competition over the status of the official language has caused the division of the country in Pakistan. After the division of India and Pakistan in 1947, Bangladeshis who lived in the eastern part of Pakistan accounted for $56.4 \%$ of the total population at that time. Most of them used Bengali language, and they demanded that Bengali be considered as one of the national languages. At that time, the main leaders of the Pakistani countries blindly followed the "one country, one mandarin language" model adopted by most countries in the world. They gave unreserved refusal to Bangladeshis' request. The latter government declared Urdu to be the only one national language. This seriously hurt the ethnic sentiments of the East Pakistani people and led to the later split, namely the independence of Bangladesh[4].

\section{Colloquialization of main Ethnic Languages}

Since ethnic languages are used only in ethnic areas, and as the status of Urdu is improved, ethnic languages are not teaching languages in primary and secondary schools in the country and are used only by local people. Most parents do not want children to concentrate too much on learning ethnic languages. Therefore, ethnic languages are used mostly by the people who cannot write or read, they will be degenerate into oral languages.

\section{National Separatism}

In addition to the main six languages in Pakistan, there are still quite a few ethnic languages, which cannot be developed because most of them cannot enter schools. The areas in which these languages are located are often poor areas. The local people often equate the marginalization of ethnic languages with the marginalization of ethnic groups. As a result, national separatist movements have begun and even religious extremism has developed.

\section{E. Other Causes of these Problems}

The above problems are also caused by some other factors.

\section{1) Educational factors}

In Pakistan, the literacy rate of over 10 -year-old people is $58 \%$, and educational resources are poor and unbalanced. Schools in big cities are taught in English, while rural schools use Urdu language to teach them. This exacerbates social status conflicts.

\section{2) Political Factors}

Pakistan's strategic position is important. Therefore, major countries and many neighboring countries have secretly supported some of Pakistan's domestic forces, or engage in ethnic separatist activities, or engage in religious extremism. They aim to weaken the Pakistani regime or use Pakistan as a base to conduct separatist and terrorist activities.

\section{3) Economic factors}

In Pakistan, the gap between the upper-class and lowerclass strata in society is large. The middle-class people are not really cultivated. Although the economy has been developing rapidly in recent years, the poverty rate is still high, and the sustainable development potential is not great.

\section{4) Religious factors}

Pakistan is a single Muslim country, but there are a large number of different sectarians and doctrines of Muslims in the country. In particular, religious extremism has a large 
market in the border areas and poor areas, which has adversely affected the country and society.

\section{ENLIGHTENMENT TO THE FORMULATION OF CHINESE LANGUAGE POLICY}

\section{A. Promotion of Chinese Mandarin}

Drawing on the experience and lessons learned from Pakistan's language policy, China's promotion of Mandarin must keep a basic national policy for a long time and should not be shaken. The implementation of national language as one of the measures for cultivating national awareness should not be ignored. We should unite all ethnic groups and oppose separatism by promoting Mandarin Chinese. The formulation and implementation of specific policies must take into account the ethnic sentiments and actual conditions of all ethnic groups. Do not use simple and crude promotion models. Use gradual, acceptable and inoffensive promotion methods, such as shooting excellent Mandarin films, television works and TV programs, to achieve the purpose.

\section{B. Foreign Language}

In Pakistan, the social status of English has never been able to be shaken. This is not good for the development of Pakistan. However, at the same time, in the context of globalization, it seems somewhat out of place the English language to disengage and abandon English. Therefore, China must keep a clear head to use foreign languages, mainly English. We shouldn't be hostile to English, or even implement a closed-door policy. Nor should we allow it to develop unlimitedly so as to abandon our culture and lose our cultural confidence. Its use and promotion should be controlled within a reasonable range.

\section{Dialects and Ethnic Language}

Many Pakistan's dialects are basically declining, and the decline of national languages will inevitably lead to the decline of national culture. The economics of China is stronger than that of Pakistan, so we have the ability to protect and develop various dialects. However, China is a multi-ethnic country with numerous dialects. The historical origins and status of these dialects are different, and the policies adopted should be differentiated. First of all, for the main dialects in Chinese, as the characters they use are the same as those used in Putonghua, we should strive to protect them so as to achieve the purpose of maintaining Chinese cultural heritage and diversity of Chinese; for the other dialects belonging to the Sino-Tibetan language family, we should protect the dialects and their culture. The protection can also be coordinated with the development of the local cultural industry; for other ethnic languages within the country, belonging to other language groups - especially if they are the same with the language used by ethnic groups in other country, we should make the policy carefully. We should respect and recognize the ethnic minorities' language and cultural rights. We should promote the use of Putonghua while paying attention to cultural identity and ethnic identity.

\section{Communication with Pakistan}

China should promote Chinese language in Pakistan, not only through regular Chinese language international promotion methods, such as the exchange of overseas students, the training of local teachers, the dispatch of Chinese teachers, the establishment of Confucius Institutes, etc., but also using other methods, such as directly funding primary and secondary schools established by the local government, running Chinese teachers to some religious schools, supporting local media to increase "Chinese Channel" or "China Channel", full strength Funding scholars of various universities for Chinese or Chinese studies, the establishment of free technical training schools, etc. Through these methods, China can gain more direct recognition and support from all walks of Pakistan.

\section{ACKNOWLEDGMENT}

This research project is partly supported by Science Foundation of Beijing Language and Culture University (supported by "the Fundamental Research Funds for the Central Universities") (18YJ080202), (17PT03)and partly supported by Science Foundation of Beijing Language and Culture University (supported by "Young Elite Teacher Project").

\section{REFERENCES}

[1] G. Zhou, "Pakistan under the New Situation and China-Pakistan Relations Keeping Pace with the Times," Asia-Pacific Security and Maritime Affairs, vol. 4, 2013, pp.28-32,59-60.

[2] G. H. Zhang, "Pakistan's Strategic Position and the Future of ChinaPakistan Relations," South Asian Studies Quarterly, vol. 2, 2011, pp14-18, pp112.

[3] Z. J. Man, Y. Xie and J. Ai, "An Analysis of Language and National Relations in Pakistan," Journal of Jiangsu Normal University(Philosophy and Social Sciences Edition), vol. 3, 2011, pp16-20.

[4] J. F. He, "Foreign multinational countries' language policy and ethnic relations," Journal of South-Central University for Nationalities(Humanities and Social Sciences), vol. 4, 2011, pp11-15.

[5] X. Q. Fu, "Pakistan's national religions," International Data Information, vol. 2, 2003, pp26-33.

[6] Y. L. Wang and Q. L. Yuan, "Analysis on the Phenomenon of Public Affairs of Private Education in Basic Education in Pakistan," Education Exploration, vol. 11, 2013, pp153-155.

[7] Z. M. Guan and R. J. Wang, "Language Planning and Dispute after Independence in Pakistan," Around Southeast Asia, vol. 7, 2004, pp60-64. 